DOI: 10.32370/IA_2021_06_17

\title{
The Dual Education System as a Key Element for Future Railway Experts at the Beginning of the 21st Century
}

\author{
Kovalenko Oleksandr \\ ORCID https://orcid.org/0000-0001-7900-6226 \\ Kherson State University \\ Post-graduate student, Prof. Ye. Petukhov Department of Pedagogy, Psychology \\ and Educational Management (Ukraine, Kherson)
}

\begin{abstract}
The article deals with the dual education system as a key element for railway experts training at the beginning of the 21 -st century. The author points out that the dual education system is of key importance for railway experts training as it provides balanced growth and in-depth knowledge of the major, develops the hard and soft skill of future specialists. It is stated that a similar system of education existed in Ukraine in the second half of the 21-st century. This system was rather successful and guaranteed new professional employees for the railway industry. The author demonstrates some information on the number of hours that were given for dual education in the past. The paper also draws out attention to the current situation in Ukraine, shows the main trends and the progress of the dual system of education nowadays. The author concludes that the most effective way of teaching future railway experts is to teach them in the enterprise giving more than $50 \%$ of total credits for practical, not theoretical courses. Thus, it is important to use historical experience and to implement it in the present education system.
\end{abstract}

Key words: a dual system of education, railway experts, hard skills, soft skills, training within the industry.

Introduction. Nowadays (at the beginning of the 21-st century) under the globalisation conditions future experts are to be competitive in the global labour market. The railway industry is one of the key industries in the Ukrainian economy. At present, railway experts' training is extremely relevant as old methods are not efficient and new trends are implementing rather slowly. One of the leading teaching methods worldwide is the dual education system which provides balanced experts training including future railway experts.

A lot of Ukrainian and foreign researchers investigated the problem of railway experts training: V. Bahlay, O. Bessarabova, O. Hruzdieva, I. Karapetiants, N. Labareshnykh, T. Marushchak, I. Skliarenko, E. Tumazu, Ya. Kharder, O. Khomuliak, T. Sharhun, E. Shefiieva, etc. The issues investigated by these scientists cover a wide range of problems such as railway experts training under globalisation conditions, reforming and modernisation of the Ukrainian education system, the comparative analysis of railway workers training in Ukraine and abroad, etc. 
Problem statement. In recent decades the dual education system has been researched by various scientists using different approaches and trends. Thus, the dual education system as an adult education model was researched by M. Dernova (2014), the dual education system for skilled staff training as a way to reform higher educational institutions is investigated by R. Oleksenko (2017). O. Korkun, I. Korkun and O. Tsilnyk (2018) analyse the dual education system as a guarantee for workforce capacity. O. Boltianskyi and N. Boltianska (2020) cover the problem of the dual education system as a way to professional mobility of graduates in higher educational institutions.

However, the dual education system in the railway industry has still been understudied. The papers which cover the mentioned above problem include an article by L. Polishchuk (2018) who investigate the implementation of the dual education system for railway staff training; the work by V. Bakatanova and V. Bahlay (2018) who highlight an expert evaluation of the dual education system in a work training centre; a collective work by S. Panchenko, S. Prikhodko, O. Kameniev, A. Lapko, L. Vasyleha, Yu. Tereshchenko (2020) who research the prospective growth of the dual education system for railway highly trained professionals training.

The article aims to investigate the practice of the implementation of the dual education system in vocational educational institutions in Ukraine which train future railway experts.

The materials and the results of the research. The term "dualism", "dual", "duality" (from Latin "dualis" - dual) is widely used in various fields of knowledge (philosophy, politology, economics, social and natural sciences). In educational sciences "dual education system" was first used in Germany in the mid-60s for a new form of professional education which later were widespread in other German-speaking countries (Austria, Switzerland). The dual education system is defined as a system that combines training in a vocational educational institution and at the enterprise [1].

One of the countries where the dual education system has been widespread for several decades is Germany. The dual education system is supported by the government there. The main enterprise which prepares future railway workers is a state-owned private company "Deutsche Bahn". The enterprise implements the dual education system to recruit new employees and to upgrade the qualification of the employed staff. The governmentally 
supported program "Chance Plus" allows school leavers who were not able to enrol on any educational institution to get a vocational education at railway enterprises [7, p. 39].

In Ukraine, railway experts training at the enterprises existed in the second half of the 21-st century and was considered highly efficient. In the mentioned above period, the necessity of railway staff training at the enterprises was caused not because of the growth of the education system but due to the lack of new employees for the railway industry because of the fast development of the railway industry [10, p. 223].

This period was highlighted by the new document which regulated the training for railway staff at the enterprises titled "Requirements for academic syllabi and curriculum for training and upgrading qualifications of the staff at the enterprises" (1983). The main points of the document are the following: common requirements to the knowledge and skills of employees of the same qualification category not depending on the form of study; the continuity between the basic railway education and further qualification upgrade of the staff. The training of new employees at the enterprise lasted 22 weeks ( 5 months) having 875 hours in total. The most amount of hours (486) was given for training with industry (TWI). TWI took place within the whole period of learning except the last week of study where students had consultations and final exams. The part of the training was titled special courses and it took 210 hours and lasted from the first up to the fifteenth week of study. Basic technical courses took place from the first up to the fifteenth week of study as well. The weekly academic load was limited to 41 hours per week during the whole period of study except the last week [4, p. 140].

In those years, the curriculum for training new workers at the enterprise (in particular, future railway experts) included not only theoretical but also TWI training.

The TWI training programme, as a rule, was formed based on qualification characteristics, syllabi and curriculum.

The TWI training programme was intended to reveal the content of training in training workshops and production facilities, at the testing grounds, as well as at the workplaces of the enterprise. In addition to acquiring professional knowledge, during the training students learnt work requirements on the railway transport, staff in-house rules, sanitary and safety rules on the railroad, work safety instructions, functional statements for railway professions and other occupational instructions of the railway industry. 
In the 80 s of the 21-st century "Requirements for academic syllabi and curriculum for training and upgrading qualifications of the staff at the enterprises" regulated the content and the volume of the academic materials which are necessary for training and upgrading qualification of experts from the basic to the highest level. The initial syllabi and curriculums were designed for the initial level training. The term of study could not be more than 6 months. The academic syllabi and curriculums for the next categories include only necessary extra knowledge, skills and abilities for each profession. If the volume of the next programme was not big enough then it was possible to combine two categories. Academic syllabi also were designed considering previous knowledge, skills and abilities which had been obtained during secondary education [9].

At the current stage in Ukraine, the dual education system was piloted within 20152017. At that time the pilot project was done based on the following educational institutions: The Kyiv higher vocational school No. 33 (occupation "Cook"), The Lviv higher art vocational school (occupation "House painter"), Zaporizhzhia higher machine-building vocational school (occupation "Turner").

The first graduation of three experimental groups proved positive results of the dual education system - up to $97 \%$ increase of employment, the quality of training increased up to $12-17 \%$, additional financial benefits - up to 50 thousand hryvnias in each educational establishment, the decrease of expenses for utilities and other expendable supplies and materials, more stable and mutually winning relationships

with employers [3].

Joint-stock company (JSC) "Ukrzaliznytsia" started implementing the dual education system in 2018. It was used for skilled workers training together with the vocational educational institutions according to the order of 22 September 2018 No. 600 "About implementation of the elements of the dual education system into the vocational educational training". This project involves 4 regional branches of JSC Ukrzaliznytsia: Pivdenna Zaliznytsia (The Southern Railroad), Odeska Zaliznytsia (Odesa Oblast Railroad), PivdennoZakhidna Zaliznytsia (The Southern-Western Railroad), Prydniprovska Zaliznytsia (The Dnieper Region Railroad) and 6 vocational educational institutions: Liubotyn Vocational Lyceum, Znamianka Vocational Lyceum, the Kudriashov higher vocational school (in Kyiv), the Koziatyn higher regional vocational school, Melitopol comprehensive vocational centre, 
Kryvyi Rih vocational Lyceum of transport and metallurgy. The initial project included students. For further development in 2019-2020 JSC "Ukrzaliznytsia" engaged 14 vocational educational institutions as well all branches of JSC and the branch "Pasazhyrska kompaniia" (Passenger Company") [2].

Nowadays, the dual education system of Ukraine is at the stage of establishment and implementation but it is possible to define the main ways of application of dual educational techniques. It could be done either by having the part of laboratory classes, practical lessons and/or seminars at the enterprises or by making individual projects which are connected with the operation of the branch where students have dual learning. The latter can be fulfilled through term papers, research technical papers, diploma papers, etc. [5, p. 40].

To our mind, taking into account the previous historical background, it would make sense to arrange future railway experts training at enterprises with the participation of the employees who work at the enterprise. TWI has to take more than half of the total teaching hours. Such an approach provides balanced acquirement by competencies as well as communicative skills, teamwork, critical thinking, etc.

Conclusions. To summarize, it is possible to say that at the beginning of the XXI century the dual education system is a key element for future railway experts training. The pilot project as to the implementation of the dual education system in vocational educational institutions is the beginning of the transition to the dual system of education in various field of knowledge, including the railway industry. The process of the implementation of the dual education system for future railway experts has a lot of advantages which were mentioned in the article. But it has as well several challenges which are as follows: scheduling of academic hours between an educational institution and the enterprise, establishing of special academic departments at the enterprise which are responsible for teaching, labour expenses for those railway employees at the enterprise who are engaged in training of students, the shortage of academic workload in educational establishments, etc. all of the above have to be discussed with stakeholders, community and be regulated by the government.

\section{References}

1. Boychevska I. Rol systemy dualnoii osvity u profesiyniy pidgotovtsi molodi $u$ Nimechchyni [The role of the dual education system in a professional training of the youth in Germany]. Studies in Comparative Education, 2009. No. 2. URL: http://pps.udpu.edu.ua/article/view/18067 
2. Dualna osvita u zaliznychniy haluzi [Dual education system in the railway industry]. URL : https://www.railinsider.com.ua/v-uz-rozpovily-yak-vprovadzhuyetsya-dual

3. Dualna osvita [The dual education system]. URL : http://www.mon.gov.ua/ua/osvita/profesijno-tehnichna-osvita/dualna-osvita

4. Rjvalenko O. M. Pidhotovka maybutnikh fakhivtsiv zaliznychnoho transportu na pdpriiemsttvakh Ukrainy (80-ti - pochatok 90-kh rr. XX st.) [Future railway experts training at the enterprises of Ukraine (80-s - the beginning of the 90-s of the XX century)]. Teoretykometodolohichni osnovy rozvytku osvity ta upravlinnia navchalnymy zakladamy: the proceedings of the VI Ukrainian (with a foreign participation) scientific-practical conference (20 November 2020, Kherson). Kherson: KVNZ "Khersonska academia neperevnoii osvity", 2020, Vol. I. Pp. 137-141.

5. Panchenko S., Prykhodko S., Kameniev O., Lapko A., Vasyleha L., \& Tereshchenko Yu. Prospects for the development of dual education in the preparation of highly qualified specialists in railway transport. New Collegium, 2020. No. 1. Pp. 36-47. doi : https://doi.org/10.30837/nc.2020.1.36

6. Petko L. V. Vyklyky XXI stolittia dlia osvitnoho prostoru Ukrainy. Naukovi pratsi

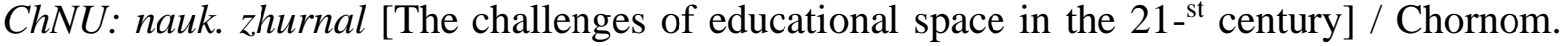
Nats. un-t im. Petra Mohyly; red. Kol.: O.P.Meshchaninov (holova) [ta in.]. - Mykolaiv: Vydvo ChNU imeni Petra Mohyly, 2017. Issue 303. Vol. 291. Pp. 10-14 (Pedahohika).

7. Sliusarenko N. V., Kovalenko A. N. Podgotovka spetsialistov zheleznodorozhnogo transporta: mezhdunarodnyy opyt [Training of Railway Transport Specialists: International Experience]. Doklady Kazakhskoy akademii obrazovaniya / redkol. Kusainov (glava) i dr. Astana, 2018. No. 5. Pp. 38-46.

8. Slyusarenko N. V., Soter M. V. Problemy movnoi pidhotovky $v$ tekhnichnykh zakladakh vyshchoi osvity Ukrainy (pochatok XXI stolittia) [Problems of language training in technical institutions of higher education of Ukraine (beginning of the 21st century)]. Teoretyko-metodolohichni osnovy rozvytku osvity ta upravlinskoi diialnosti: mat. V Vseukr. nauk.-prakt. konf. (12-13 veresnia 2019 r.) Kherson: KVNZ "Khersonska akademiia neperervnoi osvity", 2019. P. 183-186.

9. Trebovaniya $k$ razrabotke uchebnykh planov $i$ programm dlya podgotovki $i$ povysheniia kvalifikatsii rabochykh na proizvodstve: ot 19 yanvarya 1983 goda [Requirements for the development of curricula and programs for training and advanced training of workers in production: January 19, 1983]. URL: http://docs.cntd.ru/document/420273676

10. Shepelev I. A. Problema povysheniya kvalifikacii i podgotovki novyh kadrov dlya zheleznodorozhnoj otrasli SSSR v usloviyah ee modernizacii (1965-1985 gg.) [The problem of advanced training and training of new personnel for the USSR railway industry in the context of its modernization (1965-1985)]. Tambov: Gramota, 2017. No. 4. Pp. 223-226.

11. Pet'ko L. Global educational trends in the Ukrainian space. Problems of the development of mofern science: theory and practice: Collection of scientific articles. Cartero Publishing House, Madrid, España, 2018. P. 226-232. 
12. Slyusarenko N., Soter M. The Webquest as a Means of Improving the Efficiency of Students' Foreign Language Training of Ukrainian Technical Institutions of Higher Education (Beginning of the 21st Century). Intellectual Archive. Toronto: Shiny Word.Corp. (Canada). 2020. Vol. 9 (April/June). No. 2. Pp. 94-104. Doi:

https://doi.org/10.32370/IA_2020_06_13

13. Ternopilska V. I., Andruschenko I. S. Features of Formation of Future RadioElectronic Specialists' Technical Competence. Intellectual Archive. 2015. Volume 4. No. 6 (November). Toronto: Shiny Word Corp., Canada. Pp. 114-119.

\section{Translation of the Title, Abstract and References to the Author's Language}

\section{УДК 378:656.2-051(477.7)(09)«19/20»(043.3)}

Коваленко Олександр. Дуальна освіта як ключовий елемент підготовки майбутніх фахівців залізничного транспорту на початку ХХI століття

У статті досліджується система дуальної освіти як ключовий елемент підготовки фахівців залізничного транспорту на початку XXI століття. Автор зазначає, що система дуальної освіти $\epsilon$ ключовою для підготовки спеціалістів залізничного транспорту, оскільки вона забезпечує збалансований розвиток та глибокі знання за фахом, розвиває тверді та м'які навички майбутніх фахівців. Зазначається, що подібна система освіти існувала в Україні у другій половині XX століття. Ця система була досить успішною і забезпечувала залізничну галузь новими спеціалістами. У статті надається інформацію щодо кількості годин, які відводились на дуальну освіту в минулому столітті. Акцентовано увагу на сучасну ситуацію щодо дуальної освіти в Україні, висвітлюються основні тенденції та прогрес дуальної системи освіти в наш час. Зроблено висновок, що найефективніший спосіб навчання майбутніх фахівців залізничної галузі - це їх навчання на підприємстві, виділяючи більше 50\% загальної кількості годин підготовки для практичних, а не теоретичних курсів. Отже, важливо використовувати минулий досвід та впроваджувати його в сучасну систему освіти.

Ключові слова: дуальна система освіти, фахівці-залізничники, тверді навички, м'які навички, виробниче навчання.

\section{Лimepamypa}

1. Бойчевська I. Роль системи дуальної освіти у професійній підготовці молоді у Німеччині. Studies in Comparative Education, 2009. № 2. URL: http://pps.udpu.edu.ua/article/view/18067 (дата звернення: 15.05.2021).

2. Дуальна освіта у залізничній галузі. URL : https:/www.railinsider.com.ua/v-uzrozpovily-yak-vprovadzhuyetsya-dual (дата звернення 19.05.2021).

3. Дуальна освіта. URL : http://www.mon.gov.ua/ua/osvita/profesijno-tehnichnaosvita/dualna-osvita (дата звернення 19.05.2021).

4. Коваленко О. М. Підготовка майбутніх фахівців залізничного транспорту на підприємствах України (80-ті - початок 90-х рр. ХХ ст.). Теоретико-методологічні основи розвитку освіти та управління навчальними закладами: матеріали VI Всеукраїнської (з іноземною участю) науково-практичної конференції (20 листопада 2020 року, м. Херсон). Херсон: КВНЗ «Херсонська академія неперервної освіти», 2020. Ч. I. C. 137-141. 
5. Панченко С., Приходько С., Каменєв О., Лапко А., Василега Л. \& Терещенко Ю. Prospects for the development of dual education in the preparation of highly qualified specialists in railway transport. New Collegium, 2020. № 1. C 36-47. UR:https://doi.org/10.30837/nc.2020.1.36

6. Петько Л. В. Виклики XXI століття для освітнього простору України. Наукові nраиі [Чорноморського державного університету імені Петра Могили комплексу "Києво-Могилянська академія"]. Серія : Педагогіка : наук. журн. / Чорном. держ. ун-т імені Петра Могили; ред. кол. : О. П. Мещанінов (голова) [та ін.]. Миколаїв : Вид-во ЧНУ імені Петра Могили, 2017. Т. 303. Вип. 291. С. 10-14.

7. Слюсаренко Н. В., Коваленко А. Н. Подготовка специалистов железнодорожного транспорта: международный опыт. Доклады Казахской академии образования. Астана, 2018. № 5. С. 38-46.

8. Слюсаренко Н., Сотер М. Проблеми мовної підготовки в технічних закладах вищої освіти України (початок XXI століття) / Теоретико-методологічні основи розвитку освіти та управлінської діяльності: мат. V Всеукр. наук.-практ. конф. (12-13 вересня 2019 р., м. Херсон) / за ред. Кузьменка В., Слюсаренко Н.: у II ч. Ч. II. Херсон: КВНЗ «Херсонська академія неперервної освіти», 2019. С. 183-186.

9. Требования к разработке учебных планов и программ для подготовки и повышения квалификации рабочих на производстве: от 19 января 1983 года. URL : http://docs.cntd.ru/document/420273676 (дата звернення 20.04.2021).

10. Шепелев И. А. Проблема повышения квалификации и подготовки новых кадров для железнодорожной отрасли СССР в условиях ее модернизации (1965-1985 гг.). Грамота, 2017. № 4. С. 223-226.

11. Pet'ko L. Global educational trends in the Ukrainian space. Problems of the development of mofern science: theory and practice: Collection of scientific articles. Cartero Publishing House, Madrid, España, 2018. P. 226-232.

12. Slyusarenko N., Soter M. The Webquest as a Means of Improving the Efficiency of Students' Foreign Language Training of Ukrainian Technical Institutions of Higher Education (Beginning of the 21st Century). Intellectual Archive. Toronto : Shiny Word.Corp. (Canada). 2020. Vol. 9 (April/June). No. 2. Pp. 94-104. DOI: https://doi.org/10.32370/IA_2020_06_13

13. Ternopilska V. I., Andruschenko I. S. Features of Formation of Future RadioElectronic Specialists' Technical Competence. Intellectual Archive. 2015. Volume 4. No. 6 (November). Toronto: Shiny Word Corp., Canada. PP. 114-119. 